\title{
Ultrahigh-activity immune inducer from Endophytic Fungi induces tobacco resistance to virus by SA pathway and RNA silencing
}

Chune Peng ${ }^{1+}$, Ailing Zhang ${ }^{1+}$, Qingbin Wang ${ }^{2,3}$, Yunzhi Song ${ }^{1}$, Min Zhang ${ }^{3}$, Xinhua Ding ${ }^{4}$, Yang Li Quanzheng Geng ${ }^{2}$ and Changxiang Zhu ${ }^{1 *}$

\begin{abstract}
Background: Plant viruses cause severe economic losses in agricultural production. An ultrahigh activity plant immune inducer (i.e., ZhiNengCong, ZNC) was extracted from endophytic fungi, and it could promote plant growth and enhance resistance to bacteria. However, the antiviral function has not been studied. Our study aims to evaluate the antiviral molecular mechanisms of ZNC in tobacco.

Results: Here, we used Potato X virus (PVX), wild-type tobacco and NahG transgenic tobacco as materials to study the resistance of ZNC to virus. ZNC exhibited a high activity in enhancing resistance to viruses and showed optimal use concentration at 100-150 ng/mL. ZNC also induced reactive oxygen species accumulation, increased salicylic acid (SA) content by upregulating the expression of phenylalanine ammonia lyase (PAL) gene and activated SA signaling pathway. We generated transcriptome profiles from ZNC-treated seedlings using RNA sequencing. The first GO term in biological process was positive regulation of post-transcriptional gene silencing, and the subsequent results showed that ZNC promoted RNA silencing. ZNC-sprayed wild-type leaves showed decreased infection areas, whereas ZNC failed to induce a protective effect against PVX in NahG leaves.

Conclusion: All results indicate that ZNC is an ultrahigh-activity immune inducer, and it could enhance tobacco resistance to PVX at low concentration by positively regulating the RNA silencing via SA pathway. The antiviral mechanism of ZNC was first revealed in this study, and this study provides a new antiviral bioagent.
\end{abstract}

Keywords: Potato $X$ virus, Salicylic acid, $\mathrm{H}_{2} \mathrm{O}_{2}$, RNA silencing, Antivirus

\footnotetext{
* Correspondence: zhchx@sdau.edu.cn

${ }^{+}$Chune Peng and Ailing Zhang contributed equally to this work.

${ }^{1}$ State Key Laboratory of Crop Biology, College of Life Sciences, Shandong

Agricultural University, Tai'an, Shandong 271018, P.R. China

Full list of author information is available at the end of the article
}

(C) The Author(s). 2020 Open Access This article is licensed under a Creative Commons Attribution 4.0 International License, which permits use, sharing, adaptation, distribution and reproduction in any medium or format, as long as you give appropriate credit to the original author(s) and the source, provide a link to the Creative Commons licence, and indicate if changes were made. The images or other third party material in this article are included in the article's Creative Commons licence, unless indicated otherwise in a credit line to the material. If material is not included in the article's Creative Commons licence and your intended use is not permitted by statutory regulation or exceeds the permitted use, you will need to obtain permission directly from the copyright holder. To view a copy of this licence, visit http://creativecommons.org/licenses/by/4.0/ The Creative Commons Public Domain Dedication waiver (http://creativecommons.org/publicdomain/zero/1.0/) applies to the data made available in this article, unless otherwise stated in a credit line to the data. 


\section{Backgroud}

Viruses are biotrophic parasites and important pathogens of plants and cause a range of severe plant diseases and immense annual losses of yield. To date, chemical reagents are widely used to prevent or control plant diseases in agriculture [1]. However, the extensive use of agrochemicals has caused pernicious pesticide residues and environmental pollution, declined crop quality, and threatened human health. Innovative and ground-breaking strategies are therefore urgently required to control the plant viral pathogens and improve grain output because of the growing world population [2, 3].

Biological control with endophytic strains is a promising measure to control plant diseases and eliminate pollution at the same time $[4,5]$. In most cases, endophytes can produce bioactive secondary metabolites to inhibit pathogens, such as bacteria, fungi, and insects, or improve the resistance to pathogens $[3,6,7]$. The application of endophytes in biocontrol is limited because of unclear mechanism and exceptional growth condition [8]. The biocontrol agent ZhiNengCong (ZNC), which is an extract of an endophytic fungus, has been widely used in China; it is a new, efficient, environment-friendly extract. ZNC functions as an elicitor not only protecting crops from Pseudomonas syringae $p v$. tomato (Pst) DC3000 but also promoting crop growth [9]. In this study, we found that $\mathrm{ZNC}$ induces resistance to viruses at very low concentration, and the antivirus mechanism was studied.

RNA silencing is a conserved surveillance mechanism that plays a key role in defending plants against invasive nucleic acids [10-13], such as viruses, by sequence-specific degradation of complementary mRNA transcripts (post-transcriptional gene silencing, PTGS) [14, 15]. Double-stranded RNA, which is a replication intermediate generated by viral RNAdependent RNA polymerases (RDRPs) of plantinfecting RNA viruses, triggers RNA silencing [16]. This intermediate is then cleaved into short 21-24nucleotide small interfering RNA (siRNA) by an RNaseIII-like enzyme called dicer-like proteins (DCL) [17-20]. Double-stranded siRNAs are incorporated into RNA-induced silencing complex (RISC) containing an argonaute (AGO) protein that has an small RNA-binding domain and an endonucleolytic activity for the cleavage of target RNAs and then follows the sequence-specific cleavage of target RNAs [21].

Salicylic acid (SA) is a key plant hormone that mediates host responses against microbial pathogens. This plant hormone induces important plant defense response against pathogens [22-26]. Previous studies have shown a possible overlap between RNA-silencing pathway and signal transduction pathways governed by
SA [27-30]; for example, the NtRDRP activity has been increased in tobacco plants after SA treatment [29].

In this study, Potato $X$ virus (PVX) and tobacco were used as materials to study the antiviral function of the plant immune inducer $\mathrm{ZNC}$. We found that $\mathrm{ZNC}$ induced a serious defense response in plants, including $\mathrm{H}_{2} \mathrm{O}_{2}$ accumulation, $\mathrm{SA}$ accumulation, and RNA silencing. SA biosynthesis and signaling transduction pathways are required for the ZNC-mediated defense response. This study is the first to reveal the antiviral mechanism of ZNC. The results will provide a new antiviral bioreagent and help increase the application of the plant immune inducer ZNC crop biological control in the future.

\section{Results}

ZNC protected plants against virus infection

To examine the antiviral activity of $\mathrm{ZNC}$ on plant, we performed an infection assay with $N$. benthamiana and PVX, which has GFP-YFP tag (Fig. S1). The $\mathrm{H}_{2} \mathrm{O}-\mathrm{PVX}$ leaves (the plant was inoculated with PVX after water treatment) showed high fluorescence intensity (Fig. 1a) and large PVX quantity (Fig. 1b). The typical symptoms of virus disease occurred 5 days post inoculation (dpi). On the contrary, the symptoms of plants treated with $100 \mathrm{ng} / \mathrm{mL}$ of ZNC displayed a significant reduction in disease severity, and the relative quantity of PVX from the ZNC -PVX group was only $31.77 \%$ compared with that from the $\mathrm{H}_{2} \mathrm{O}$-PVX group (Fig. $1 \mathrm{a}$ and $\mathrm{b}$ ). To further confirm the function of $\mathrm{ZNC}$ - induced resistance against virus, leaves was inoculated with PVX before spraying $\mathrm{ZNC}$ and $\mathrm{H}_{2} \mathrm{O}$. The results showed that $\mathrm{ZNC}$ could prevent virus infection to some extent (Fig. S2), and the relative quantity of PVX in $\mathrm{ZNC}$ treatment leaves was lower than that in the $\mathrm{H}_{2} \mathrm{O}$ group (74.42\%). However, the difference was insignificant in comparison with the ZNC treatment (31.77\%) (Fig. 1). These results suggest that ZNC prevents virus by enhancing the plant resistance to virus but does not cure the plant. Besides, ZNC also improve plant resistance to Tobacco mosaic virus (TMV), but have lower resistance to TMV than that to PVX on tobacco (Fig. S3).

The optimum concentration of ZNC was determined using a gradient concentration aqueous solution of $\mathrm{ZNC}$ at $0,50,100,150$, and $200 \mathrm{ng} / \mathrm{mL}$. The results showed that the antivirus function of $\mathrm{ZNC}$ was gradually enhanced with the increase in its concentration. Nonetheless, when the concentration of ZNC was $200 \mathrm{ng} / \mathrm{mL}$, the plant presented wilting. We hence used $150 \mathrm{ng} / \mathrm{mL}$ of $\mathrm{ZNC}$ in the next experiment.

\section{ZNC promoted hydrogen peroxide accumulation}

Abiotic stresses generally enhance the production of cellular ROS and cause oxidative damage. To investigate 

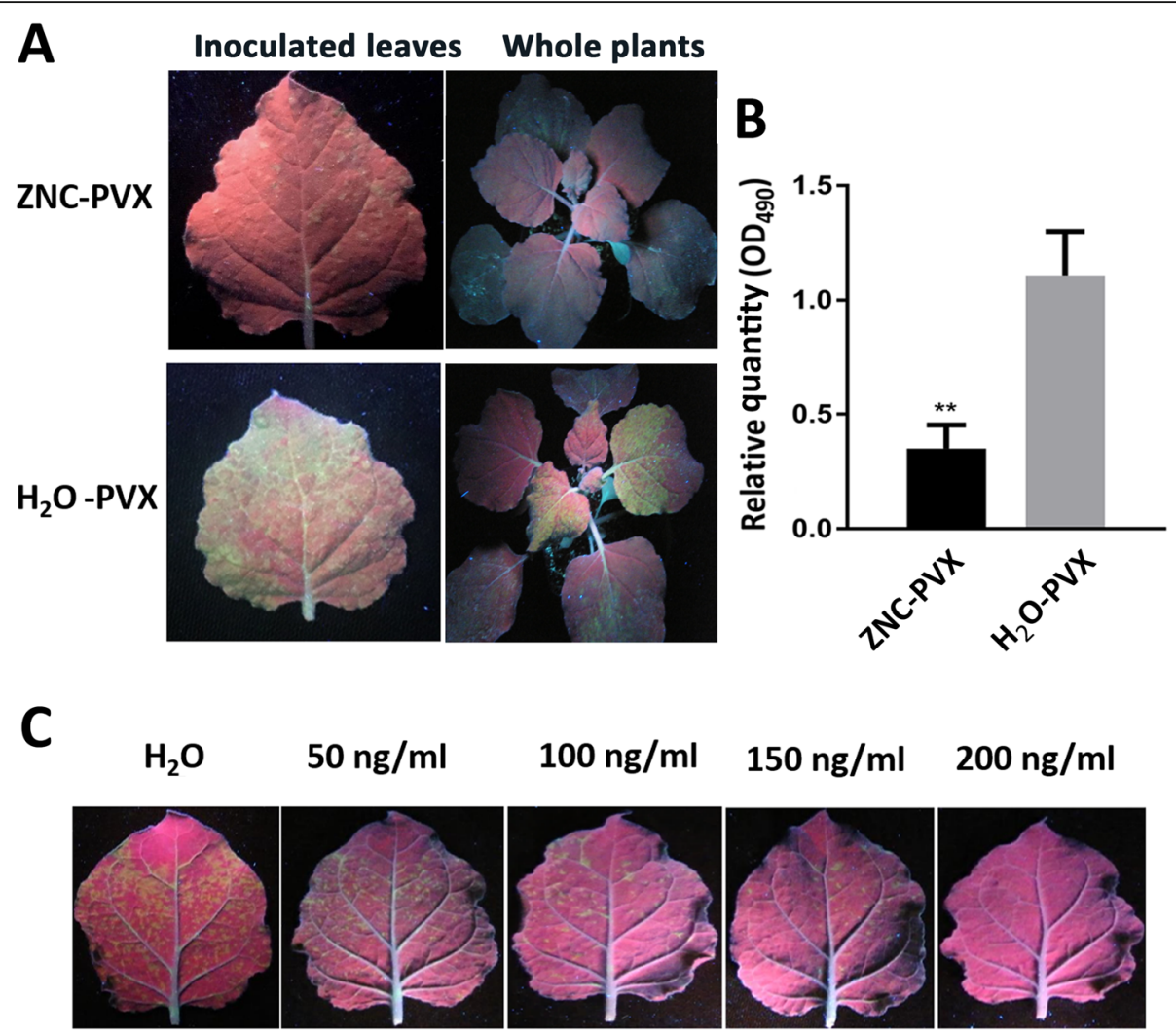

\section{$100 \mathrm{ng} / \mathrm{ml}$}

$150 \mathrm{ng} / \mathrm{ml}$

$200 \mathrm{ng} / \mathrm{ml}$

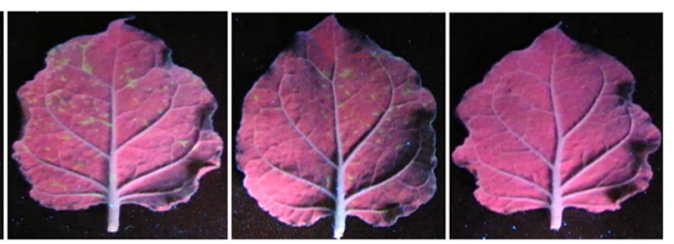

Fig. 1 ZNC treatment enhanced plant resistance against PVX. Wild-type N. benthamiana was inoculated with PVX (GFP and YFP tag) after ZNC $(100 \mathrm{ng} / \mathrm{mL})$ treatment for $2 \mathrm{~h}$, the phenotype (a) was obtained under long-wave ultraviolet lamp, and PVX relative expression quantity (b) was calculated using ELISA method at $5 \mathrm{dpi}$. The emerging areas were measured using a gradient concentration $(0,50,100,150$, and 200 ng/mL) ZNC (c). Error bars show the mean \pm SD of three replicates (at least 20 plants per replicate). ** indicates extremely significant differences determined using the Student's t-test $(p<0.01)$

whether ZNC regulates ROS accumulation, DAB (3,3-diaminobenzidine) and NBT staining were applied to evaluate the levels, namely, $\mathrm{H}_{2} \mathrm{O}_{2}$ and $\mathrm{O}^{2-}$, in leaves that were detached from the water-spraying group and 150 $\mathrm{ng} / \mathrm{mL} \mathrm{ZNC}$-spraying group. Figure $2 \mathrm{a}$ and $\mathrm{b}$, show that $\mathrm{DAB}$ staining was first strengthened and then weakened with the extension of time. The DAB staining was the deepest after $2 \mathrm{~h}$ of spraying $\mathrm{ZNC}$, which indicated the accumulation of $\mathrm{H}_{2} \mathrm{O}_{2}$ was elevated.

The mRNA levels of several important ROSscavenging enzymes encoding genes, namely, catalase (CAT), superoxide dismutase (SOD), ascorbate peroxidase (APX), and ROS-generating-related genes, including respiratory burst oxidase homolog genes (RbohA and RbohB), were determined by qRT-PCR analysis and monitored before and after treatment. After ZNC treatments, the expression levels of $C A T, S O D$, and $A P X$ dramatically decreased at $2 \mathrm{~h}$ post-treatment (hpt) compared with those in control group plants (Fig. 2c). By contrast, the expression levels of RbohA and RbohB were markedly increased (Fig. 2d). This phenomenon indicates that the accumulation of hydrogen peroxide is regulated by reducing $C A T$ expression and increasing $R b o h B$ expression. These results suggest that ZNC may improve $\mathrm{H}_{2} \mathrm{O}_{2}$ production to relieve ROS toxicity but not ROS scavenging.

\section{ZNC promoted the SA biosynthesis and activated the SA} signaling pathway

The SA sample extraction was determined with sufficient intensity by using HPLC and gave satisfactory results. The standard addition method was used for validation because the presence of SA was detected in almost every sample (Fig. 3). The relative concentration of SA was determined by Empower software and standard SA. The changes in amount of SA induced by ZNC at different time $(2,4,6,8 \mathrm{~h})$ in Nicotiana. benthamiana leaves were detected, and the results showed that the SA concentration was first increased and then decreased with the extension of time, and reached its concentration maximum at $6 \mathrm{~h}$ in Fig. 3. The results suggest that ZNC promotes SA accumulation to activate the defense response. 

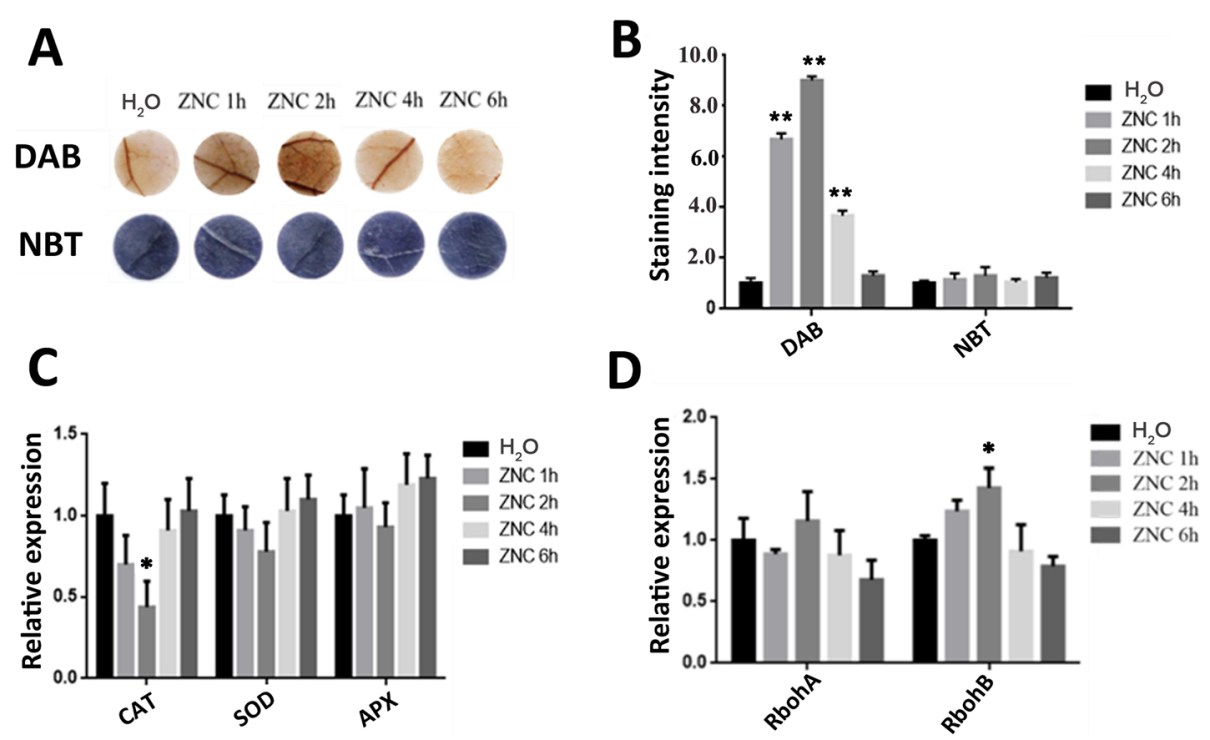

Fig. 2 ZNC promoted hydrogen peroxide accumulation. ZNC promoted hydrogen peroxide accumulation in $N$. benthamiana. Hydrogen peroxide (up) and superoxide accumulation (down) were measured in leaves treated with $150 \mathrm{ng} / \mathrm{mL}$ of ZNC at different $(0,1,2,4,6)$ hours post treatment (hpt) $(n=5)$. Quantification of hydrogen peroxide and superoxide levels in $N$. benthamiana treated with $150 \mathrm{ng} / \mathrm{mL}$ of ZNC at $0,1,2,4$, and 6 hpt. Data are shown as the mean $(n=5) \pm S D$. CAT, SOD, and APX were detected using qRT-PCR at various time intervals. Data are shown as the mean $(n=5) \pm$ SD.qRT-PCR analysis of RbohA and RbohB expression at various time intervals. Data are shown as the mean $(n=5) \pm S D . *$ indicates significant differences determined using the Student's t-test $(p<0.05)$, ** indicates extremely significant differences determined using the Student's t-test $(p<0.01)$.

Plants synthesize SA mainly by ICS and phenylalanine ammonia lyase (PAL) pathway. Thus, we detected the ICS and $P A L$ genes using qRT-PCR. The results showed that $P A L$ gene was upregulated by $\mathrm{ZNC}$, whereas ICS gene basically remained unchanged (Fig. 4a). These results imply that ZNC promotes SA synthesis by improving $P A L$ transcription level.

Pathogenesis-related (PR) proteins play an important role in plant defense. They can improve plant disease resistance by inhibiting virus reproduction and mainly

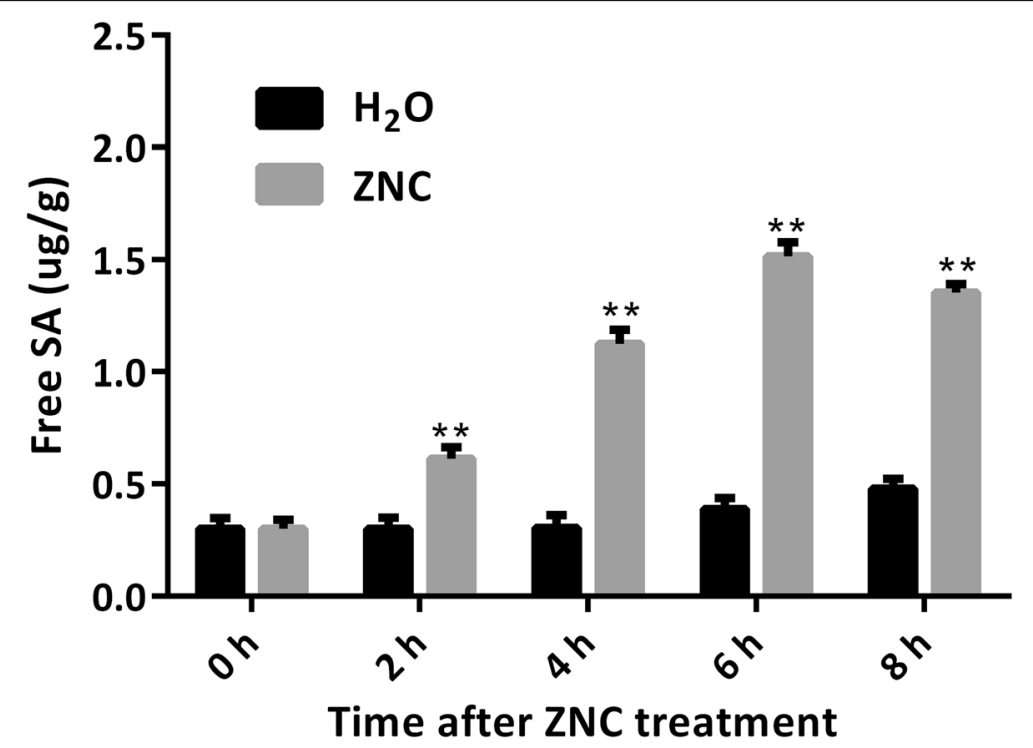

Fig. 3 Accumulation of free SA in Nicotiana. Benthamiana induced by ZNC. The plants were treated with $150 \mathrm{ng} / \mathrm{mL}, \mathrm{SA}$ was extracted at different time points. Values are the mean of three replicates \pm SD $(n=3) .{ }^{* *}$ indicates extremely significant differences determined using the Student's t-test $(I<0.01)$. 

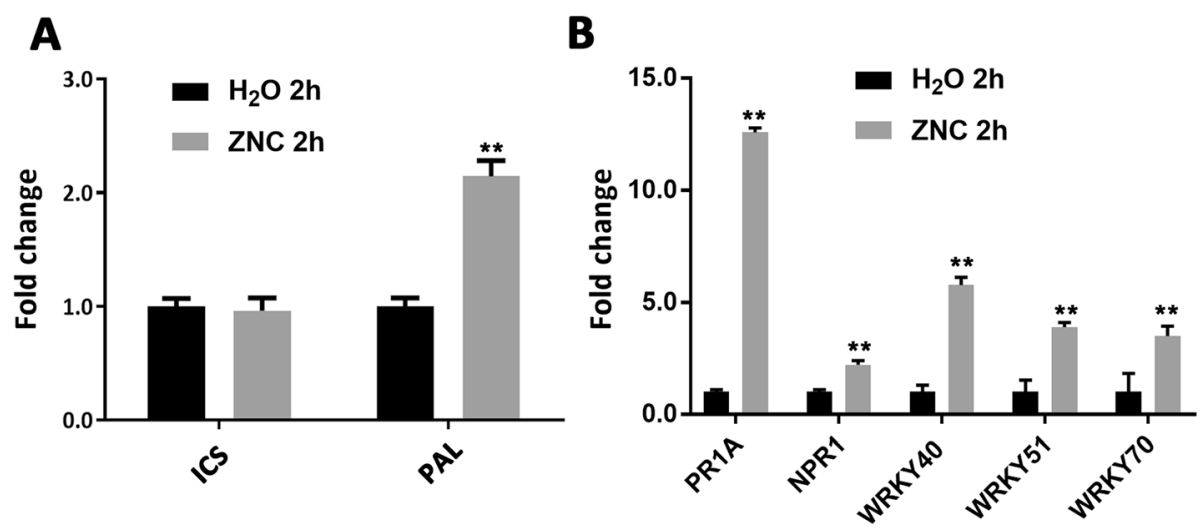

Fig. 4 ZNC promoted SA signal transduction and SA biosynthesis. a SA biosynthesis-associated gene ICS1 and PAL were measured at $2 \mathrm{hpt}$ using qRT-PCR (means \pm SD, $n \geq 3$ ). b SA signaling-associated genes NPR1, WRKY40, WRKY51, and WRKY70 were measured at 2 hpt using qRT-PCR (means $\pm S D, n \geq 3)$. ${ }^{*}$ indicates extremely significant differences determined using the Student's t-test $(p<0.01)$.

involved in plant-acquired systemic resistance. They can also be highly expressed in plants with the induction of SA [22, 31, 32]. PR-1A and nonexpressor of PR (NPR) are the key factors in the SA pathway, involved in $N$. benthamiana resistance to viruses [33] or other pathogens, such as phytophthora infestations [34]. WRKYs can bind the promoter region of NPR and have functions in the SA signaling pathway [35-37]. The high expression of WRKY4O and WRKY7O in tobacco can increase resistance to pathogens [38]; the overexpression of WRKY70 can enhance the expression of SA-responsive $P R$ genes [39]; SA is increased in Arabidopsis mutants by the positive regulation of WRKY genes, including WRKY51 [40]. WRKY transcription factor genes are involved in hormone signaling pathways, such as SA pathway [41]. Furthermore, the expression patterns of several WRKY genes are significantly increased in tobacco after virus infection $[42,43]$. To confirm the results, we detected the relative genes $P R$ $1 A$ (belonging to the PR1 family), NPR1, WRKY4O, WRKY 51, and WRKY70, by using qRT-PCR. The results showed that the expression level of the above genes was upregulated (Fig. 4b). ZNC can promote SA synthesis and activate the SA signaling pathway to enhance the defense response.

\section{Quantitative differences in gene expression in $N$. benthamiana after ZNC treatment}

To further reveal the role of ZNC in inducing plant resistance, a nonparametric transcriptome sequencing analysis was performed on leaves treated with ZNC. The leaves were harvested after $2 \mathrm{~h}$ of $150 \mathrm{ng} / \mathrm{mL}$ ZNC treatment. More than 47 million clean reads were generated (Table S2). A total of 2801 genes were upregulated twofold, and 1983 genes were downregulated $(P<0.05)$ in $N$. benthamiana plants treated with $150 \mathrm{ng} / \mathrm{mL}$ of ZNC compared with those treated with $\mathrm{H}_{2} \mathrm{O}$ at $2 \mathrm{hpt}$ (Fig. 5a and b). Most of the ZNC-regulated genes at $2 \mathrm{hpt}$ belong to a very wide range of $\mathrm{GO}$ categories, such as those related to biological processes, cellular component, and molecular function (Fig. S4). The upregulated GO term (Table 1) of biological process included positive regulation of PTGS, defense response, and response to SA (Fig. 5c). Within KEGG classification, plant hormone signal transduction genes showed the highest expression changes, and 95 differentially expressed genes (DEG) were upregulated (Fig. 5d and Fig. S5). Thus, we speculate that the resistance to PVX was induced by RNA silencing via SA pathway.

\section{ZNC enhanced RNA silencing}

The results of transcriptome sequencing showed that the ZNC could positively regulate the PTGS. Thirty $N$. benthamiana were sprayed with $\mathrm{ZNC}$ and deionized water to study the effect of ZNC on RNA silencing. After $2 \mathrm{~h}$, the Agrobacterium culture $\left(\mathrm{OD}_{600}=1.0\right)$ harboring pBI121-GFP was injected into leaves, and RNA silencing was determined by observing the GFP fluorescence intensity in the infiltrated and newly emerging leaves under long-wavelength ultraviolet light for 7 days. Then, GFP emerging leaves were collected, the total RNA was extracted, and the expression levels of GFP were detected by qRT-PCR. As shown in Fig. 6, the GFP fluorescence intensity was strongest at $3 \mathrm{dpi}$, and the GFP fluorescence intensity and expression level of the ZNC treatment group were significantly lower than those of the control group at $3 \mathrm{dpi}$ (Fig. $6 \mathrm{a}$ and b). Moreover, siRNA was extracted, and Northern blot was performed. The GFP siRNA accumulation of the ZNC treatment group was higher than that of the control group (Fig. 6c). The above-mentioned results suggest that ZNC promotes RNA silencing.

$\mathrm{DCL}$ and $\mathrm{AGO}$ are the key proteins in the RNAsilencing pathway. DCL is responsible for cutting the 


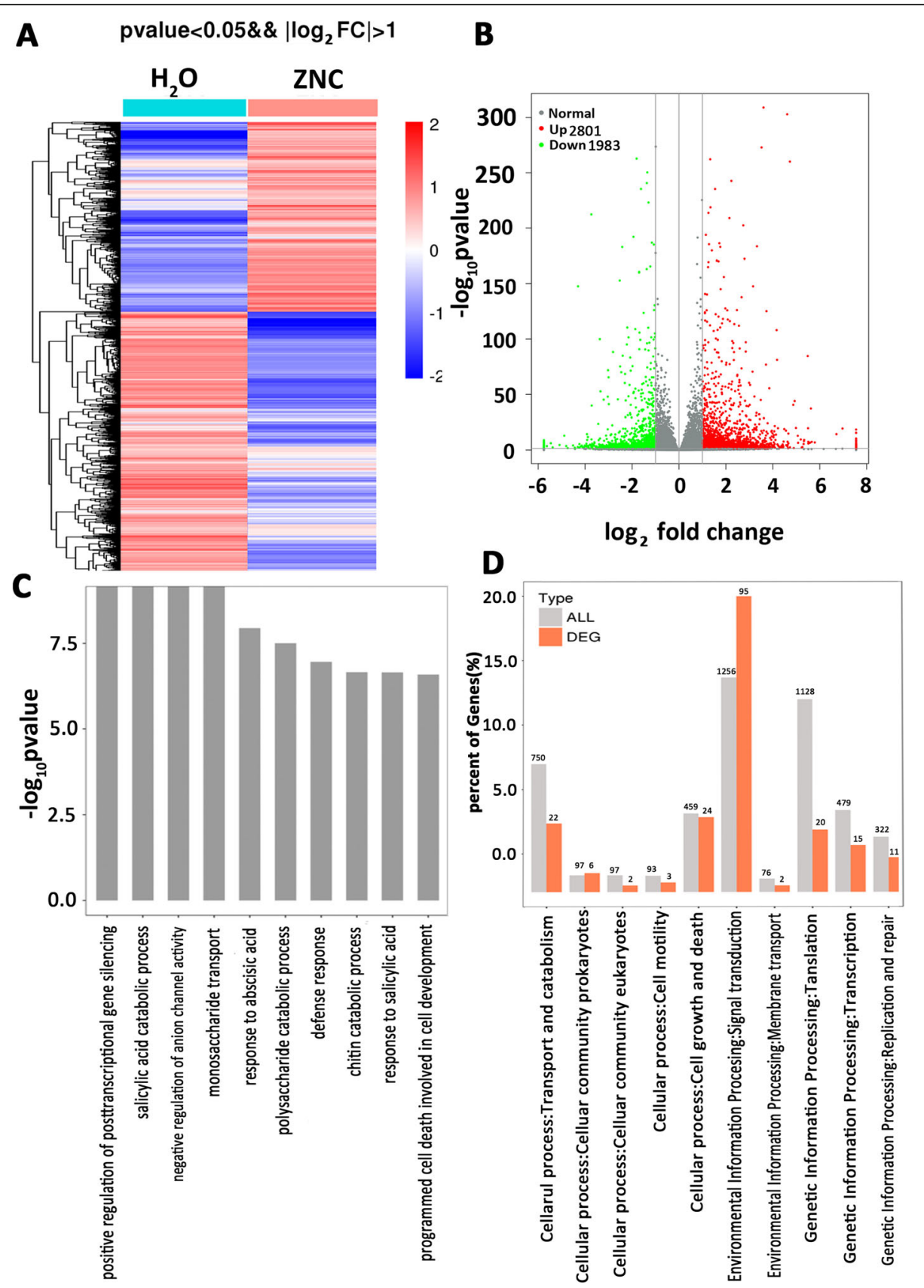

Fig. 5 Transcriptome analysis after ZNC treatment in Nicotiana. Benthamiana. RNA samples were taken from five or six leaf stage leaves, which were treated with $0\left(\mathrm{H}_{2} \mathrm{O}\right)$ or $150 \mathrm{ng} / \mathrm{mL}$ of $\mathrm{ZNC}$ for $2 \mathrm{~h}$. Each treatment contain three samples (plants). a A set of comparison heatmap for ZNC treatment at $2 \mathrm{hpi}$. The red color in the figure indicates the high-expression genes, and the blue color indicates the low-expression genes. $\mathbf{b}$ Volcano plot showing fold change and adjusted $p$-value of normalized read counts of the transcriptome sequencing data. The criteria of log 2 (fold change) $\mid \geq 1$ and padj $\leq 0.05$ were used to identify the DEGs. Green dots indicate the downregulated DEGs (1983 genes), and red dots indicate the upregulated DEGs (2801 genes). c GO enrichment top 10 (upregulated) term of biological process. The numbers of - $\log _{10} P$ value of differential genes between $\mathrm{H}_{2} \mathrm{O}$ and ZNC groups in every term $>2$ were screened, and the top 10 terms were sorted by the - $\log _{10} P$ value corresponding to each term. $\mathbf{d}$ Partial KEGG pathway classification. Abscissa axis is the ratio of DEG in a pathway: all DEG in KEGG level 2 pathway $(\%)$, ordinate axis is the name of pathway. The numbers above the column represent the quantity of DEG in the pathway.

dsRNA produced by cells, and AGO acts as a catalytic component of RNA-induced silencing complex (RISC), which promotes amplified silencing signal. The genes related to RNA-silencing pathway were detected by qRT-
PCR. NbDCL1, NbDCL2, NbDCL3, NbDCL4, NbRDR6, $\mathrm{NbAGO7}$, and $\mathrm{NbAGO10}$ were upregulated; among these genes, $N b D C L 3$ and $N b A G O 10$ were significantly upregulated (Fig. 6d). Hence, ZNC plays a role of silencing 
Table 1 Gene ontology (GO) enrichments of upregulated genes

\begin{tabular}{llll}
\hline GO_Accession & Description (Term) & DEG Number & category \\
\hline GO:0060148 & positive regulation of posttranscriptional gene silencing & 3 & biological_process \\
GO:0046244 & salicylic acid catabolic process & 3 & biological_process \\
GO:0010360 & negative regulation of anion channel activity & 5 & biological_process \\
GO:0015749 & monosaccharide transport & 3 & biological_process \\
GO:0009737 & response to abscisic acid & 40 & biological_process \\
GO:0000272 & polysaccharide catabolic process & 9 & biological_process \\
GO:0006952 & defense response & 43 & biological_process \\
GO:0006032 & chitin catabolic process & 8 & biological_process \\
GO:0009751 & response to salicylic acid & 18 & biological_process \\
G0:0010623 & programmed cell death involved in cell development & 4 & biological_process \\
GO:0004568 & chitinase activity & 8 & molecular_function \\
G0:0010200 & response to chitin & 12 & biological_process \\
\hline
\end{tabular}

A

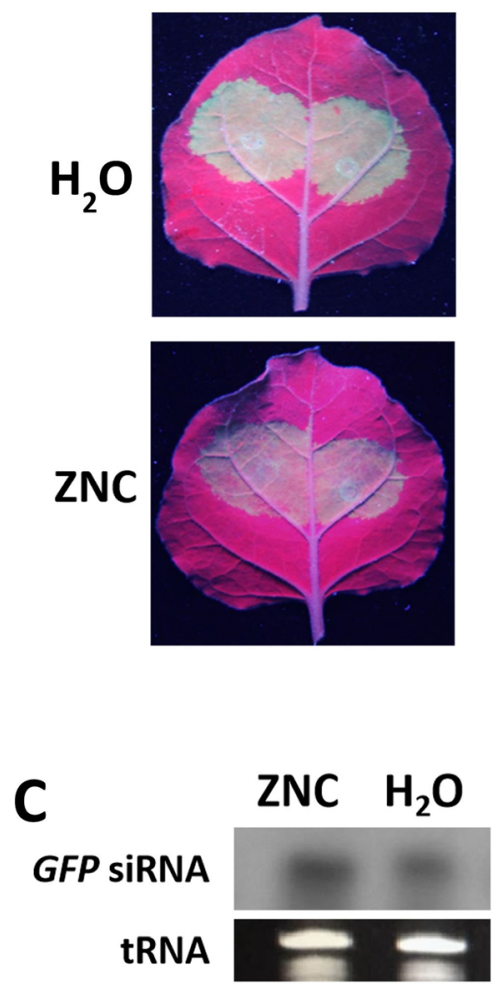

B
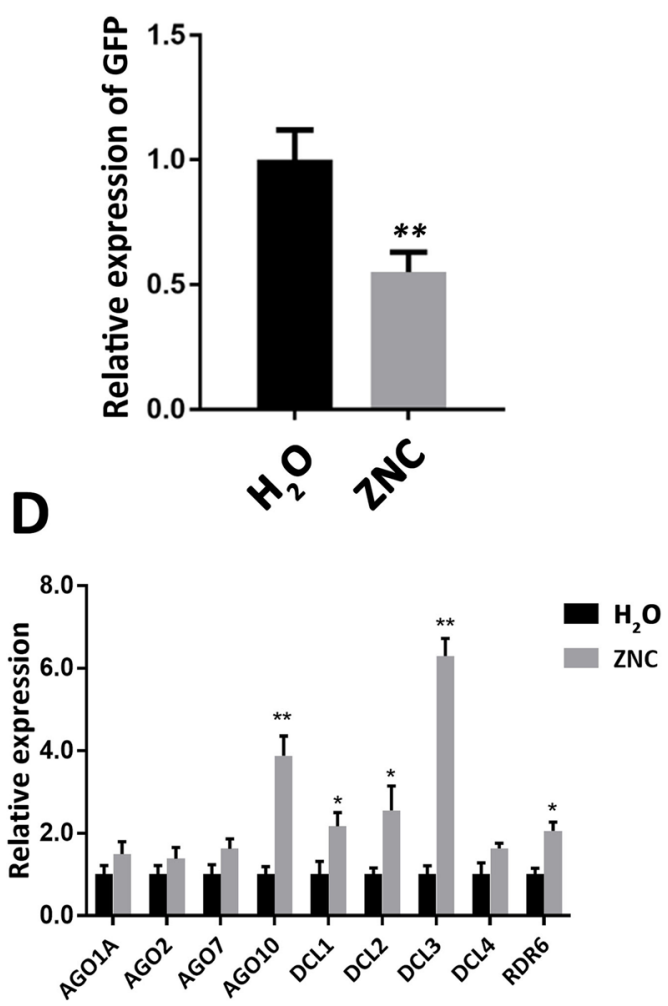

Fig. 6 ZNC enhanced RNA silencing. a N. benthamiana leaves were inoculated with Agrobacterium harboring PB/121-GFP after water (up panel) or $150 \mathrm{ng} / \mathrm{mL}$ of ZNC (down panel) treatment for $2 \mathrm{~h}$. Then, the leaves were examined under UV light at $3 \mathrm{dpi}$. $\mathbf{b}$ The relative expression level of GFP was detected by qRT-PCR. Data are shown as the mean $(n=3) \pm S D$, and ${ }^{* *}$ indicates extremely significant differences determined using the Student's t-test $(p<0.01)$. c Northern blot analysis of GFP siRNA extracted at $3 \mathrm{dpi}$ from patches, the cropped gel and blot images were shown in Fig. $6 c$, and tRNA was used as loading control for siRNA. $\mathbf{d}$ The relative expression of genes related to RNA silencing pathway was detected using qRT-PCR after ZNC treatment for $2 \mathrm{~h}$. Data are shown as the mean $(n=3) \pm S D$. * indicates significant differences determined using the Student's t-test $(p<0.05)$, and ${ }^{* *}$ indicates extremely significant differences determined using the Student's t-test $(p<0.01)$. 
enhancement by regulating the upstream pathway of RNA silencing.

\section{ZNC promoted RNA silencing through SA pathway}

Previous studies have shown SA induce RNA silencingrelated genes and plant resistance to RNA pathogens [28]. So we speculate that ZNC induced virus resistance by RNA silencing through SA pathway. To test this speculation, NahG transgenic $N$. tabacum cv Samsun $N N$ was used as plant material. SA could not accumulate because SA was broken down into catechins. In a transient expression experiment, we could see that the fluorescence intensity of GFP was the strongest at 3 dpi emerging area and then gradually decreased. However, the GFP fluorescence intensity showed no significant change between ZNC treatment leaves and water treatment group, and the expression levels of GFP from the two treatment areas were consistent with the phenomenon (Fig. 7a and b). On the contrary, the GFP fluorescence intensity of the nontransgenic plant treated with ZNC was significantly decreased compared with that of the nontransgenic plant sprayed with water, and the GFP expression level was consistent with the fluorescence intensity.
To further confirm the results, NahG transgenic $N$. tabacum cv Samsun NN and wild-type N. tabacum cv Samsun NN plants were inoculated with PVX by rubbing leaves with sap. The PVX accumulation (Fig. 7d) was more and the emerging area was larger in the water treatment group than in the $\mathrm{ZNC}$ treatment group in the wild-type tobacco at $15 \mathrm{dpi}$. For NahG transgenic $N$. tabacum cv Samsun NN, the PVX accumulation and emerging area showed no significant difference (Fig. 7c). The results indicate that ZNC cannot induce antivirus ability for NahG transgenic N. tabacum cv Samsun NN and SA-deficient plants. All the results mentioned above suggest that ZNC promotes RNA silencing through SA pathway and then induces virus resistance.

\section{Discussion}

Most plants possess endophytes (mostly bacteria and fungi), and endophytes can promote growth and plant health in most cases. During long-term coevolution with plants, endophytic bacteria and fungi have developed many factors that help plants resist stresses and promote their growth. For instance, endophytic microbes are often functional in that they may increase the stress tolerance of plants, enhance disease resistance in of plants,

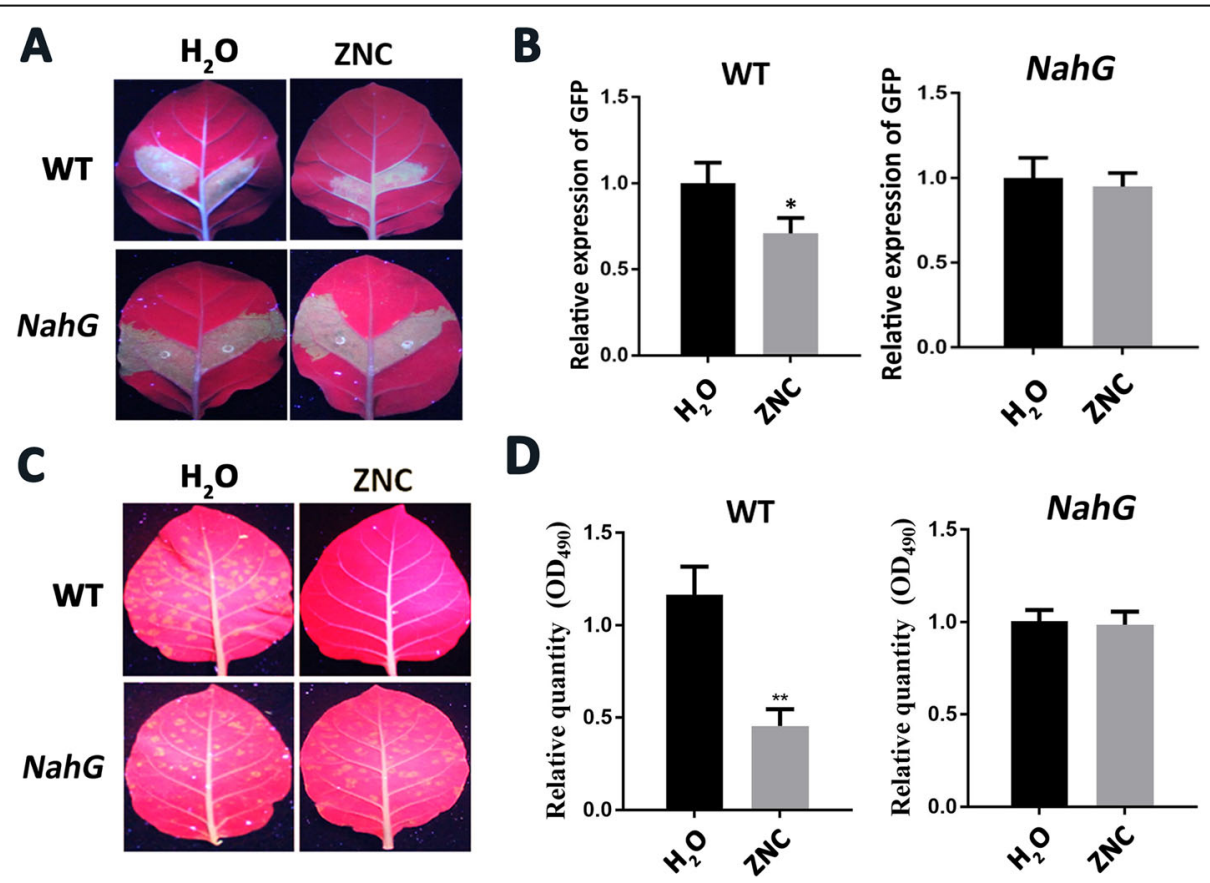

Fig. 7 ZNC induced the antiviral activity of plants by increasing RNA silencing via SA pathway. a Photograph of wide type N. tabacum cv Samsun NN (up panel) and NahG transgenic N. tabacum cv Samsun NN (down panel) infiltrated with Agrobacterium harbouring PB/121-GFP after water (left panel) or ZNC (right panel) treatment, under an ultraviolet lamp at 3 dpi. b The relative expression levels of GFP from wild-type plants and NahG transgenic plants were detected by qRT-PCR. Data are shown as mean $(n=3) \pm \mathrm{SD}$. * indicates significant differences determined using the Student's t-test $(p<0.05)$. c Effect of ZNC on PVX-GFP accumulation in wild-type N. tabacum cv Samsun NN (up panel) and NahG transgenic N. tabacum cv Samsun NN (down panel). The photographs were taken under an ultraviolet lamp at $3 \mathrm{dpi}$. The plants were treated with water (left panel) or ZNC (right panel). d The relative expression relative quantity of PVX from wild-type plants and NahG transgenic plants were detected by qRT-PCR. Data are shown as mean $(n=3) \pm$ SD. ${ }^{*}$ *indicates significant differences determined using the Student's t-test $(N<0.01)$. 
suppress virulence in pathogens, restrain the development of competitor plant species, and carry nutrients from soil into plants. Endophytic microbes may significantly reduce the use of agrochemicals (fertilizers, fungicides, insecticides, and herbicides) in the cultivation of crop plants because of the effective functions of endophytic microbes [44-46]. However, the number of biocontrol agents used in agriculture is very small. ZNC, which is a commercialized product, is the crude extract of a $P$. variotii strain, which is isolated from the roots of plants [9]. ZNC has been used on crops, vegetables and fruit trees widely, and the molecular mechanisms of plant growth promotion and bacterial disease protection have been evaluated recently. To further understand the antiviral mechanism of $\mathrm{ZNC}$, we investigated $\mathrm{ZNC}$ mediated virus resistance in tobacco. In our study, we found that ZNC cannot cure virus-infected plants, but it has prophylactic function, enhances the resistance to virus in plants (Fig. 1 and S3). $\mathrm{ZNC}$ can promote $\mathrm{H}_{2} \mathrm{O}_{2}$ (Fig. 2), SA accumulation (Fig. 3), and activate RNA silencing (Fig. 6a and b). These data confirm that ZNC acts as an elicitor of active defense responses in plants. The antiviral mechanism of ZNC was first revealed in this study.

Many elicitors, which can induce plant defense response and protect them from pathogen infection have been identified [47]; they include flagellin [48], elongation factor [49], chitin [50, 51], and other oligosaccharide (e.g., oligogalacturonide acid, OGs) [52]. They are pathogen-associated molecular patterns (PAMPs) and interact with plant receptors that active the PAMPtriggered immunity [53-55]. However, the abovementioned elicitor's effective concentration is between $\mu \mathrm{g} / \mathrm{mL}$ and $\mathrm{mg} / \mathrm{mL}$ in order of magnitude, which is considerably higher than the working concentration of ZNC (ng/mL), such as Flg22 $(1 \mu \mathrm{M}$, approximately $2.232 \mu \mathrm{g} /$ $\mathrm{mL})$ and OGs $(50 \mu \mathrm{g} / \mathrm{mL})$ [48]. Moreover, several plant hormones' working concentration is higher than that of $\mathrm{ZNC}$; for example, the antiviral concentration of SA is $10 \mu \mathrm{M}$, approximately $1.38 \mu \mathrm{g} / \mathrm{mL}$ [26]. ZNC is the fermentation extract from $p$. variotii, mainly containing nucleoside, saccharides, protein and other compounds (data not shown). We do not know which molecular is an effective elicitor that induces plant resistance to virus because we cannot acquire single compound. Hence, further research is required to separate, extract, and identify effective compounds.

Abiotic stress generally enhances the production of cellular reactive oxygen species (ROS) in plants [56]. Previously studies have shown that SA and hydrogen peroxide levels are closely correlated, and they mutually induce each other's accumulation during many biological processes [57-59]. Virus invasion causes plant hypersensitivity reaction and generates abundant hydrogen peroxide, which accelerate the cells into programmed cell death, inhibit the reproduction and spread of the virus, and enhance the resistance to virus of plant. So we believe that hydrogen peroxide plays an integral role as signaling molecules in the regulation of numerous biological processes such as responses to abiotic stimuli in plants [60,61]. Plants have ROS scavenging activity to prevent plants from its toxic effects. SOD and Rbohs are mainly responsible for generating hydrogen peroxide, which can convert harmful superoxide radicals into hydrogen peroxide, and then ROS scavenging enzymes APX and/or CAT hydrolyze hydrogen peroxide. In this study, we found that DAB staining showed a significant difference after ZNC treatment, whereas NBT staining showed no significant difference. $N b C A T$ gene related to the hydrogen peroxide-scavenging process was significantly downregulated, whereas $R b o h B$ gene was upregulated. ZNC may promote the accumulation of hydrogen peroxide by promoting the accumulation of SA; this finding needs further study.

SA biosynthesis induced by pathogen infection mainly depends on the ICS1 gene and partly depends on PAL gene. The ICS1 protein has isochorismate synthase activity, whereas PAL is a phenylalanine ammonia lyase [6264]. Interestingly, in our study the SA biosynthesis mainly depends on $P A L$ gene (Fig. 4a). The reason is unclear and requires further research.

The phytohormone SA plays important roles in regulating disease resistance. Systemic acquired resistance (SAR) depends on SA signaling in plants, such as the chemical benzothiadiazole induces SAR by increasing endogenous SA levels $[65,66]$. Previous studies have shown that exogenous SA also increases PR gene expression [67]. Thus, SAR requires signal molecule SA and is associated with the accumulation of PR proteins, which are supposed to contribute to resistance [22]. In our study, the SA content in plants increased after spraying $\mathrm{ZNC}$, and the related marker genes PR1A, NPR1, WRKY40, WRKY51 and WRKY 70 in SA pathway were upregulated by qRT-PCR (Fig. 4b). These results confirm that the biosynthesis of SA dependent on PAL is required in the ZNC-mediated defense response.

Transcriptome sequencing showed that many different genes were upregulated; such genes are involved in various aspects, such as positive regulation of PTGS, SA catabolic process, response to SA, and defense response (Fig. 5, Fig. S4, S5). The aforementioned biological process is closely related to plant defense and induction of resistance. Previous studies have shown that SA induces RNA-silencing-related genes [27, 28]. Moreover, the RNA-silencing pathways modulate responses to certain stresses and can be partially tuned by SA [68], and SA-related transcription factors are coexpressed with several AGO and DCL [69]. In our study, we found that 
NbDCL1, NbDCL2, NbDCL3, NbRDR6, NbAGO7, and NbAGO10 were upregulated with SA accumulation in the marker genes of RNA-silencing pathway (Fig. 6). The results suggest that preinduction of RNA-silencingrelated genes by SA inhibits PVX accumulation.

Previous studies showed that SA induces RNA silencing-related genes and plant resistance to virus [28], and SA-deficient $N$. benthamiana attenuates virusinduced gene silencing but does not affect transgeneinduced PTGS [70]. Our study showed that ZNC could promote the accumulation of SA (Fig. 4), and transcriptome sequencing results showed that $\mathrm{ZNC}$ upregulated the expression of RNA silencing-related genes (Fig. 5). Silencing efficiency analysis showed that the fluorescence intensity of wild-type plants treated with ZNC was significantly weaker than that of the water group. However, no significant difference in fluorescence intensity in NahG transgenic plants was observed (Fig. 7a and b). Furthermore, ZNC-sprayed wild-type leaves showed decreased infection areas, whereas ZNC failed to induce a protective effect against PVX in NahG leaves. These results indicated that virus resistance can be achieved by RNA silencing via the SA pathway for ZNC. However, RNA silencing is dispensable for SA-mediated resistance against plant RNA viruses in Arabidopsis thaliana [71]. These findings suggest that SA may increase plant resistance to viruses in various of parallel resistance mechanisms, such as inducing systemic acquired resistance (SAS) [72] or acting as an enhancer of the RNA silencing antiviral defense in tobacco. SA and RNA silencing defense mechanisms may also cooperate to prevent virus invasion [73-75]. Thus, we presumed that ZNC increases plant viral resistance by enhancing RNA silencing via the SA pathway, which is a mechanism to fight diseases. Whether ZNC can improve resistance to the virus through other SA pathways remains unclear.

Furthermore, SA was found in numerous plants ( $\mathrm{Ni}$ cotiana tabacum, tomato, Arabidopsis thaliana, Orange), and could induce RNA silencing-related genes and plant resistance to RNA pathogens $[28,75]$. The previous report showed that ZNC activated the salicylic acid biosynthesis and signaling pathways in Arabidopsis thaliana [9]. In the support information, we found that ZNC also enhance N.benthamiana resistance to TMV. Therefore, we speculated that ZNC can induce the resistance to various virus through SA and RNA silencing pathway in different plants. The antiviral phenomenon of ZNC is nonspecific.

\section{Conclusions}

We firstly demonstrated that ultrahigh-activity ZNC could induce virus resistance at low concentration, and the antiviral mechanism was preliminary revealed. All results indicated that $\mathrm{ZNC}$ mediated resistance to viruses by positively regulating RNA silencing via salicylic acid SA pathway. This study provides a new antiviral bioagent, namely, ZNC. This bioagent will be very useful bioagent for plant antiviral research and application.

\section{Methods}

\section{Materials and growth conditions}

ZNC was provided by Shandong Pengbo Biotechnology Co., Ltd.; it is an ethanol crude extract of Paecilomyces variotii. The pCaPVX440-GFP-YFP plasmids were presented by professor Xiangdong Li (Shandong agricultural university, china) [76] (Fig. S1). For RNA-silencing analysis, the empty vector pBI121 with GFP tag was transformed into Agrobacterium tumefaciens GV3101 in this study. Wild-type Nicotiana benthamiana and N. tabacum cv Samsun NN were propagated and stored in this study. NahG (which encodes a salicylate hydroxylase converting SA into catechol) transgenic $N$. tabacum cv Samsun NN (from Dr. Josefa M. Allimino, campus universidad atonoma de madrid, Spain) [74] were raised in a greenhouse at $24{ }^{\circ} \mathrm{C}$ under a 16 -h light/8-h dark photoperiod. The DNA polymerase, and other genetic engineering enzymes were purchased from Takara Inc. (Dalian, China).

All other chemicals and reagents were of the highest quality available.

\section{Antivirus study of ZNC}

The wild-type $N$. benthamiana was inoculated at five or six leaf stage with Potato Virus X (PVX)-GFP-YFP before or after spraying $100 \mathrm{ng} / \mathrm{mL}$ of ZNC to confirm the resistance of ZNC to the infection of PVX. For virus inoculation, $1 \mathrm{~g}$ of PVX-infected $N$. tabacum leaves was ground in $1 \mathrm{~mL}$ of $5 \mathrm{mM}$ phosphate buffer with $\mathrm{pH}$ 7.2. Control plants at six-leaf stage were inoculated by rubbing leaves with freshly prepared sap. Inoculated plants were grown in an insect-free greenhouse at $24{ }^{\circ} \mathrm{C}$, and the viral symptom was monitored. Each experiment was replicated three times and included 10 independent plants.

A gradient concentration aqueous solution of $\mathrm{ZNC}$ at $0,50,100,150$, and $200 \mathrm{ng} / \mathrm{mL}$ was sprayed on $N$. benthamiana for $2 \mathrm{~h}$ before inoculating PVX to further determine the optimal working concentration for the antivirus of ZNC; all other conditions were the same as above. The infection of PVX was determined by observing GFP-YFP fluorescence under long-wavelength (365 nm) UV light (Spectroline Model SB-100P/A; Spectronics Corporation, Lexington, KY, USA) and photographed with a Fujifilm FinePix S8000fd digital camera (Fujifilm Holdings Corporation) [77] . The virus content was detected by enzyme-linked immunosorbent assay (ELISA) [78, 79]. The plates were followed by 
colorimetric readout using an EnSpire Multilabel Reader at $490 \mathrm{~nm}$ wavelength. Control groups were $N$. benthamiana leaves without inoculating PVX.

\section{Histochemical staining of reactive oxygen species}

The $N$. benthamiana leaves of $\mathrm{ZNC}$ and $\mathrm{H}_{2} \mathrm{O}$ treatment groups were detached for histochemical staining procedure. Staining was performed using 3,3'-diaminobenzidine (DAB) and nitroblue tetrazolium (NBT) to detect the accumulation of $\mathrm{H}_{2} \mathrm{O}_{2}$ and $\mathrm{O}_{2}{ }^{-}$. The accumulation of $\mathrm{H}_{2} \mathrm{O}_{2}$ in leaves was visualized histochemically using $\mathrm{DAB}$ as an indicator. The leaves were placed into $1 \mathrm{mg} /$ $\mathrm{mL}$ of $\mathrm{DAB}$ solution, vacuum-infiltrated for $30 \mathrm{~min}$, washed thrice with deionized water and reacted with $\mathrm{H}_{2} \mathrm{O}_{2}$ for $12 \mathrm{~h}$ under light at $28^{\circ} \mathrm{C}$. After the reaction, a deep brown deposition was clearly visible in leaves, excess dye solution was washed away with boiled ethanol and leaves were imaged.

For NBT staining, $N$. benthamiana leaves were placed into a $1 \%(\mathrm{M} / \mathrm{V})$ sodium azide solution, vacuuminfiltrated for $30 \mathrm{~min}$, transferred into a $0.5 \mathrm{mg} / \mathrm{mL}$ of NBT solution, followed by another vacuum-infiltration for $30 \mathrm{~min}$. Sodium azide may improve cell permeability for allowing the NBT solution to spread throughout the entire seedling. NBT reacted with $\mathrm{O}^{2-}$ and thus formed a dark blue insoluble complex substance. Redundant dye solution was washed away with boiled ethanol, and the leaves were imaged. ImageJ software was used for quantitative analysis of $\mathrm{H}_{2} \mathrm{O}_{2}$ and $\mathrm{O}_{2}{ }^{-}$intensity [80].

\section{SA extraction and content analysis}

After $N$. benthamiana were sprayed with $150 \mathrm{ng} / \mathrm{mL}$ $\mathrm{ZNC}$, the free SA was extracted at different time points $(0,2,4,6,8 \mathrm{~h})$ using the previous methods. Briefly, $1 \mathrm{~mL}$ of $70-\%$ methanol was added in a mortar after $0.1 \mathrm{~g}$ of seeding samples was grinded and then left overnight at $4{ }^{\circ} \mathrm{C}$. The samples were transferred into polypropylene centrifuge tubes. Extract was obtained by centrifugation $(8000 \times \mathrm{g}, 10 \mathrm{~min})$. The supernatant was then placed in another tube for evaporation $\left(\mathrm{N}_{2}, 45^{\circ} \mathrm{C}\right)$. The dry residues were reconstituted with $500 \mu \mathrm{L} \mathrm{ddH}_{2} \mathrm{O}$. A total of $300 \mu \mathrm{L}$ of extract was reconstituted with $40 \mu \mathrm{L} 0.5 \mathrm{mg} /$ $\mathrm{mL}$ Trifluoroacetic Acid (TFA), Mix and shake for 1 min. $1 \mathrm{ml}$ of ethyl acetate and cyclohexane was added for removing organic phase, the aqueous phase was then placed in another tube for evaporation $\left(\mathrm{N}_{2}, 45^{\circ} \mathrm{C}\right)$. The dry residues were reconstituted with $500 \mu \mathrm{L}$ mobile phase. Finally, an aliquot of $500 \mu \mathrm{L}$ of extracting solution was transferred to an EP tube after $0.22 \mu \mathrm{m}$ filtration (0), [81]. SA extracting solution $(10 \mu \mathrm{L})$ and SA standard were analyzed using HPLC by monitoring the absorbance at 306 $\mathrm{nm}$. All the samples were loaded on the C18 reversephase chromatographic column $(250 \mathrm{~mm} \times 4.6 \mathrm{~mm}$, $5 \mu \mathrm{m})$, respectively. Separation was eluted methanol and
$0.1 \%$ acetic acid water (the ratio is $65: 35$ ) and then eluted at $35^{\circ} \mathrm{C}$ over $30 \mathrm{~min}$ with a flow rate of $0.8 \mathrm{~mL} / \mathrm{min}$.

\section{RNA extraction and quantitative real-time PCR}

Total RNAs were extracted from leaves using Trizol reagent (TaKaRa, Shiga, Japan) in accordance with the instructions of the manufacturer and treated with DNase I at $37^{\circ} \mathrm{C}$ for $30 \mathrm{~min}$ prior to reverse transcription. cDNA was synthesized from $1 \mu \mathrm{g}$ of total RNA using FastKing gDNA Dispelling RT SuperMix kit (Tiangen, Beijing, China). Quantitative real-time (qRT-PCR) was performed using Talent SYBR Green Kit (Tiangen, Beijing, China). Each reaction was conducted in triplicate and repeated three times. The results were analyzed by BioRad CFX Manager software (Bio-Rad, California, USA). The relative expression of SOD, CAT, APX, RbohA, and $R b o h B$ were measured using qRT-PCR. Each assay was repeated three times. Primer sequences for the qRTPCR experiment are presented in Table S1.

\section{Data analysis of RNA-sequencing}

RNA samples were taken from five or six leaf stage leaves, which were treated with $0\left(\mathrm{H}_{2} \mathrm{O}\right)$ or $150 \mathrm{ng} / \mathrm{mL}$ of ZNC for $2 \mathrm{~h}$. Each treatment contain three samples (plants). The samples were selected depending on quality (RIN score $\geq 7$ ). They were pooled and sequenced by Shanghai OE Biotech. Co., Ltd. (Shanghai, China). Previous articles have provided a detailed description of how to analyze RNA-sequening data [82, 83]. All differential gene expressions were based on the following standard: the absolute value of $\log 2$ ratio $\geq 1$ and FDR $\leq 0.001$.

\section{RNA-silencing analysis}

The wild-type $N$. benthamiana, $N$. tabacum cv Samsun $N N$, and NahG Transgenic N. tabacum cv Samsun NN leaves were infiltrated at five- or six-leaf stage with Agrobacterium GV3101 carrying the GFP gene. Each Agrobacterium culture $\left(\mathrm{OD}_{600}=1.0\right)$ was incubated for $3 \mathrm{~h}$ and then mixed with other culture (s) in a 1:1 (v/v) ratio prior to infiltration. Local and systemic RNA silencing were determined by observing GFP-YFP fluorescence in the infiltrated and newly emerging leaves under long-wavelength (365 nm) UV light as described above. Silencing pathway-related genes, such as (AGO) protein, DCL protein, and RDRP were also detected by qTRPCR.

\section{Northern blot analysis of siRNA}

Low-molecular-weight RNAs were extracted from leaves as described previously [84]. For siRNA detection, $15 \mu \mathrm{g}$ of Low-molecular-weight RNAs was separated on 15\% polyacrylamide-7 $\mathrm{M}$ urea gel and transferred to a Hybond- $\mathrm{N}^{+}$membrane in $0.5 \mathrm{X} \mathrm{TBE}$ at $0.8 \mathrm{~mA} \mathrm{~cm}^{-2}$ for $1 \mathrm{~h}$. After the membrane was UV-crosslinked and 
incubated at $80^{\circ} \mathrm{C}$ for $2 \mathrm{~h}$, it was hybridized with DIG labeled probe GFP mRNA. Chemiluminescent detection was conducted using a DIG Northern Starter Kit (Roche, Basel, Switzerland) in accordance with the instructions of the manufacturer.

\section{Supplementary information}

Supplementary information accompanies this paper at https://doi.org/10. 1186/s12870-020-02386-4

Additional file 1: Fig. S1. Genomic structure of vector pCaPVX440-GFPYFP. The gfp gene was cloned into pCaPVX440 in the AsiSI site, while yfp gene was inserted between the Sacl and Mlul site. RdRp, RNA-dependent RNA polymerase; $25 \mathrm{~K}, 12 \mathrm{~K}$ and $8 \mathrm{~K}$ are movement protein; $\mathrm{CP}$, coat protein.

Additional file 2: Fig. S2. The effection of ZNC when give prior to PVX. Wild-type $N$. benthamiana was inoculated with PVX (GFP + YFP tag) before ZNC $(150 \mathrm{ng} / \mathrm{mL})$ treatment for $2 \mathrm{~h}$, the phenotype $(\mathbf{A})$ was obtained under long-wave ultraviolet lamp, and PVX relative expression quantity (B) was calculated using ELISA method at $5 \mathrm{dpi}$. Error bars show the mean \pm SD of three replicates (at least 20 plants per replicate). ${ }^{* *}$ indicates extremely significant differences determined using the Student's ttest $(p<0.01)$.

Additional file 3: Fig. S3. ZNC treatment enhanced plant resistance against TMV. Wild-type $N$. benthamiana was inoculated with TMV (GFP tag) after ZNC $(100 \mathrm{ng} / \mathrm{mL})$ treatment for $2 \mathrm{~h}$. The phenotype was obtained under irradiation with long-wave ultraviolet lamp at 7 dpi. (A) Inoculated leaves. (B) Whole plants.

Additional file 4: Fig. S4. Top $30 \mathrm{GO}$ enrichment terms. Differential genes between $\mathrm{H}_{2} \mathrm{O}$ and $Z \mathrm{NC}$ groups with a $-\log _{10} P$ value of greater than 2 in every term were screened, and the top 10 terms were sorted by the $-\log _{10} P$ value corresponding to each term. Case: $150 \mathrm{ng} / \mathrm{mL} Z \mathrm{ZNC}$; control: $0 \mathrm{ng} / \mathrm{mL}$ ZNC.

Additional file 5: Fig. S5. Kyoto Encyclopedia of Genes and Genomes (KEGG) enrichment analysis of differentially expressed genes (DEGs) in the plant in response to ZNC. The top 20 enriched pathways in the plant. Each circle represents a KEGG pathway, the $Y$-axis represents the pathway name, and the $X$-axis represents the enrichment score, which compares the ratio of genes annotated to a pathway among the DEGs to the ratio of genes annotated to that pathway among all genes. The larger the enrichment factor, the more significant the enrichment of DEGs in the pathway.

Additional file 6: Fig. S6. GFP siRNA accumulation. Northern blot analysis of GFP siRNA extracted at 3 dpi from patches, tRNAs stained by ethidium bromide were shown as loading controls for siRNAs. The pictures in the box are the same as Fig. 6c.

Additional file 7: Table S1 Primers used for sequencing in the present study. Table $\mathbf{S 2}$ The number of reads obtained from each sample. ZNC/ $\mathrm{H}_{2} \mathrm{O}$ : the treatment with $\mathrm{ZNC}$ or distilled water.

\section{Abbreviations}

DAB: 3,3-diaminobenzidine; $\mathrm{H}_{2} \mathrm{O}_{2}$ : Hydrogen peroxide; NBT: Nitroblue tetrazolium; NPR: Nonexpressor of pathogenesis-related; PAL: Phenylalanine ammonia lyase; PR: Pathogenesis-related protein; PVX: Potato virus X; ROS: Reactive oxygen species; SA: Salicylic acid; TMV: Tobacco mosaic virus: ZNC: ZhiNengCong

\section{Acknowledgments}

We are grateful to professor Xiangdong Li for providing vector $\mathrm{pCaPVX440-}$ GFP-YFP, Dr. Josefa M. Allimino for providing NahG transgenic N. tabacum CV Samsun NN, and professor Fei Yan for providing TMV-GFP.

\section{Authors' contributions}

ZCX designed the experiments, ZCX, PCE and ZAL conceived the original screening and research plans. PCE, ZAL, WQB, SYZ, LY and GQZ performed the experiments. PCE, ZAL and ZCX analyzed the data. PCE and ZCX wrote the manuscript. ZCX, ZM and DXH writing-review and editing. All authors read and agreed to publish this article.

\section{Funding}

This research was financially supported by the National Natural Science Foundation (Grant No. 31272113) to Changxiang Zhu for designing and performing experiments, and the Natural science foundation of Shandong province (ZR2019MC009) to Changxiang Zhu for data analysis, writing and revising the manuscript.

\section{Availability of data and materials}

The Transcriptome Sequence data are deposited the in the NCBI Sequence Read Archive (SRA) under accession number PRJNA616072. The datasets analyzed during the current study are available from the corresponding author on reasonable request. All data generated or analyzed during this study are included in this published article [and its supplementary information files].

Ethics approval and consent to participate

Not applicable.

\section{Consent for publication}

Not applicable.

\section{Competing interests}

The authors declare no competing interests.

\section{Author details}

${ }^{1}$ State Key Laboratory of Crop Biology, College of Life Sciences, Shandong Agricultural University, Tai'an, Shandong 271018, P.R. China. ${ }^{2}$ Shandong Pengbo Biotechnology Co., LTD, Tai'an, Shandong 271018, P.R. China. ${ }^{3}$ National Engineering Laboratory for Efficient Utilization of Soil and Fertilizer Resources; National Engineering \& Technology Research Center for Slow and Controlled Release Fertilizers, College of Resources and Environment, Shandong Agricultural University, Tai'an, Shandong 271018, P.R. China. ${ }^{4}$ State Key Laboratory of Crop Biology, College of Plant Protection, Shandong Agricultural University, Tai'an, Shandong 271018, P.R. China.

Received: 22 December 2019 Accepted: 5 April 2020

Published online: 15 April 2020

\section{References}

1. Rodriguez-Salus $M$, Bektas $Y$, Schroeder $M$, Knoth $C$, Vu T, Roberts $P$, Kaloshian I, Eulgem T. The synthetic elicitor 2-(5-Bromo-2-Hydroxy-phenyl)Thiazolidine-4-carboxylic acid links plant immunity to Hormesis. Plant Physiol. 2016;170(1):444-58

2. Gaffar FY, Koch A. Catch me if you can! RNA silencing-based improvement of antiviral plant immunity. Viruses. 2019;11(7):673.

3. Jeon CW, Kim DR, Kwak YS. Valinomycin, produced by Streptomyces sp. S8, a key antifungal metabolite in large patch disease suppressiveness. World J Microbiol Biotechnol. 2019;35(8):128.

4. Li H, Guan Y, Dong Y, Zhao L, Rong S, Chen W, Lv M, Xu H, Gao X, Chen R, $\mathrm{Li} L, X u Z$. Isolation and evaluation of endophytic Bacillus tequilensis GYLH001 with potential application for biological control of Magnaporthe oryzae. PLoS One. 2018;13(10):e203505.

5. Nisa H, Kamili AN, Nawchoo IA, Shafi S, Shameem N, Bandh SA. Fungal endophytes as prolific source of phytochemicals and other bioactive natural products: a review. Microb Pathog. 2015:82:50-9.

6. Ryan RP, Germaine K, Franks A, Ryan DJ, Dowling DN. Bacterial endophytes: recent developments and applications. FEMS Microbiol Lett. 2008;278(1):1-9.

7. Reinhold-Hurek B, Hurek T. Living inside plants: bacterial endophytes. Curr Opin Plant Biol. 2011;14(4):435-43.

8. Ownley BH, Gwinn KD, Vega FE. Endophytic fungal entomopathogens with activity against plant pathogens: ecology and evolution. BIOCONTROL. 2010; 55(1):113-28.

9. Lu C, Liu H, Jiang D, Wang L, Jiang Y, Tang S, Hou X, Han X, Liu Z, Zhang M, Chu Z, Ding X. Paecilomyces variotii extracts (ZNC) enhance plant immunity and promote plant growth. Plant Soil. 2019;441(1-2):383-97.

10. Moon JY Park JM. Cross-talk in viral defense signaling in plants. Front Microbiol. 2016;7:2068. 
11. Wu X, Valli A, Garcia JA, Zhou X, Cheng X. The Tug-of-War between Plants and Viruses: Great Progress and Many Remaining Questions. Viruses. 2019; 11(3)

12. Hannon GJ. RNA interference. NATURE. 2002;418(6894):244-51.

13. Himber C, Dunoyer P, Moissiard G, Ritzenthaler C, Voinnet O. Transitivitydependent and -independent cell-to-cell movement of RNA silencing. EMBO J. 2003;22(17):4523-33

14. Vaucheret $H$, Beclin C, Fagard M. Post-transcriptional gene silencing in plants. J Cell Sci. 2001;114(Pt 17):3083-91.

15. Vaucheret $H$, Fagard M. Transcriptional gene silencing in plants: targets, inducers and regulators. Trends Genet. 2001;17(1):29-35.

16. Ruiz-Ferrer $\mathrm{V}$, Voinnet $\mathrm{O}$. Roles of plant small RNAs in biotic stress responses. Annu Rev Plant Biol. 2009;60:485-510.

17. Hamilton AJ, Baulcombe DC. A species of small antisense RNA in posttranscriptional gene silencing in plants. SCIENCE. 1999;286(5441):950-2.

18. Lichner Z, Silhavy D, Burgyan J. Double-stranded RNA-binding proteins could suppress RNA interference-mediated antiviral defences. J GEN VIROL. 2003;84(Pt 4):975-80.

19. Lu S, Shi R, Tsao CC, Yi X, Li L, Chiang VL. RNA silencing in plants by the expression of siRNA duplexes. Nucleic Acids Res. 2004;32(21):e171.

20. Baulcombe D. RNA silencing in plants. NATURE. 2004:431(7006):356-63.

21. Vaucheret $H$, Vazquez $F$, Crete P, Bartel DP. The action of ARGONAUTE1 in the miRNA pathway and its regulation by the miRNA pathway are crucial for plant development. Genes Dev. 2004;18(10):1187-97.

22. Durrant WE, Dong X. Systemic acquired resistance. Annu Rev Phytopathol. 2004;42:185-209.

23. Fu ZQ, Dong $X$. Systemic acquired resistance: turning local infection into global defense. Annu Rev Plant Biol. 2013;64:839-63.

24. Gao QM, Zhu S, Kachroo P, Kachroo A. Signal regulators of systemic acquired resistance. Front Plant Sci. 2015;6:228

25. Tsuda K, Sato M, Stoddard T, Glazebrook J, Katagiri F. Network properties of robust immunity in plants. PLoS Genet. 2009;5(12):e1000772.

26. Wang S, Han K, Peng J, Zhao J, Jiang L, Lu Y, Zheng H, Lin L, Chen J, Yan F. NbALD1 mediates resistance to turnip mosaic virus by regulating the accumulation of salicylic acid and the ethylene pathway in Nicotiana benthamiana. Mol Plant Pathol. 2019;20(7):990-1004.

27. Liu Y, Gao Q, Wu B, Ai T, Guo X. NgRDR1, an RNA-dependent RNA polymerase isolated from Nicotiana glutinosa, was involved in biotic and abiotic stresses. Plant Physiol Biochem. 2009;47(5):359-68.

28. Campos L, Granell P, Tárraga S, López-Gresa P, Conejero V, Bellés JM, Rodrigo I, Lisón P. Salicylic acid and gentisic acid induce RNA silencingrelated genes and plant resistance to RNA pathogens. Plant Physiol Biochem. 2014;77:35-43.

29. Xie Z, Fan B, Chen C, Chen Z. An important role of an inducible RNAdependent RNA polymerase in plant antiviral defense. Proc Natl Acad Sci U S A. 2001;98(11):6516-21.

30. Quilis J, Penas G, Messeguer J, Brugidou C, San SB. The Arabidopsis AtNPR1 inversely modulates defense responses against fungal, bacterial, or viral pathogens while conferring hypersensitivity to abiotic stresses in transgenic rice. Mol Plant-Microbe Interact. 2008;21(9):1215-31.

31. Breen S, Williams SJ, Outram M, Kobe B, Solomon PS. Emerging insights into the functions of pathogenesis-related protein 1. Trends Plant Sci. 2017; 22(10):871-9.

32. Vlot AC, Dempsey DA, Klessig DF. Salicylic acid, a multifaceted hormone to combat disease. Annu Rev Phytopathol. 2009;47:177-206.

33. Villanueva-Alonzo HJ, Us-Camas RY, Lopez-Ochoa LA, Robertson D, GuerraPeraza O, Minero-Garcia Y, Moreno-Valenzuela OA. A new virus-induced gene silencing vector based on Euphorbia mosaic virus-Yucatan peninsula for NPR1 silencing in Nicotiana benthamiana and Capsicum annuum var. Anaheim Biotechnol Lett. 2013;35(5):811-23.

34. Zang H, Xie S, Zhu B, Yang X, Gu C, Hu B, Gao T, Chen Y, Gao X. Mannan oligosaccharides trigger multiple defence responses in rice and tobacco as a novel danger-associated molecular pattern. Mol Plant Pathol. 2019.

35. Liu Y, Liu Q, Tang Y, Ding W. NtPRla regulates resistance to Ralstonia solanacearum in Nicotiana tabacum via activating the defense-related genes. Biochem Biophys Res Commun. 2019;508(3):940-5.

36. Backer $R$, Naidoo $S$, van den Berg N. The NONEXPRESSOR OF PATHOGENESIS-RELATED GENES 1 (NPR1) and related family: mechanistic insights in plant disease resistance. Front Plant Sci. 2019;10:102.

37. Maier F, Zwicker S, Huckelhoven A, Meissner M, Funk J, Pfitzner AJ, Pfitzner UM. NONEXPRESSOR OF PATHOGENESIS-RELATED PROTEINS1 (NPR1) and some NPR1-related PROTEINS are sensitive to salicylic acid. Mol Plant Pathol. 2011;12(1):73-91.

38. An M, Zhou T, Guo Y, Zhao X, Wu Y. Molecular Regulation of Host Defense Responses Mediated by Biological Anti-TMV Agent Ningnanmycin. Viruses. 2019;11(9).

39. Pieterse CM, Van der Does D, Zamioudis C, Leon-Reyes A, Van Wees SC. Hormonal modulation of plant immunity. Annu Rev Cell Dev Biol. 2012;28:489-521.

40. Zhang S, Li C, Wang R, Chen Y, Shu S, Huang R, Zhang D, Li J, Xiao S, Yao $\mathrm{N}$, Yang C. The Arabidopsis mitochondrial protease $\mathrm{FtSH} 4$ is involved in leaf senescence via regulation of WRKY-dependent salicylic acid accumulation and signaling. Plant Physiol. 2017;173(4):2294-307.

41. Thomma BP, Eggermont K, Tierens KF, Broekaert WF. Requirement of functional ethylene-insensitive 2 gene for efficient resistance of Arabidopsis to infection by Botrytis cinerea. Plant Physiol. 1999;121(4):1093-102.

42. Jie Z, Dingyu Z, Yongqiang D, Dexin C, Jing W, Chao F, Fenglong W, Fangchan J, Qingbin Z, Wenjing W. Expression patterns of WRKY transcription factor genes in tobacco plants upon CMV infection and phytohormone treatment. Plant Prot. 2017;3(43):55-9.

43. Jingjing $L$, Chunling C, Yuzhen $X$, Shu W. Roles of Nicotiana tobacum NtWRKY40 in plant responding to virus infection. Biotechnol Bull. 2016; 10(32):188-98.

44. Harman GE, Uphoff N. Symbiotic Root-Endophytic Soil Microbes Improve Crop Productivity and Provide Environmental Benefits. Scientifica (Cairo). 2019;2019:9106395.

45. White JF, Kingsley KL, Zhang Q, Verma R, Obi N, Dvinskikh S, Elmore MT, Verma SK, Gond SK, Kowalski KP. Review: Endophytic microbes and their potential applications in crop management. Pest Manag Sci. 2019.

46. Schmidt CS, Mrnka L, Frantik T, Lovecka P, Vosatka M. Plant growth promotion of Miscanthus $x$ giganteus by endophytic bacteria and fungi on non-polluted and polluted soils. World J Microbiol Biotechnol. 2018;34(3):48.

47. Boller T, Felix G. A renaissance of elicitors: perception of microbe-associated molecular patterns and danger signals by pattern-recognition receptors. Annu Rev Plant Biol. 2009;60:379-406.

48. Denoux C, Galletti R, Mammarella N, Gopalan S, Werck D, De Lorenzo G, Ferrari S, Ausubel FM, Dewdney J. Activation of defense response pathways by OGS and Flg22 elicitors in Arabidopsis seedlings. Mol Plant. 2008;1(3):423-45.

49. Zipfel C, Kunze G, Chinchilla D, Caniard A, Jones JD, Boller T, Felix G. Perception of the bacterial PAMP EF-Tu by the receptor EFR restricts Agrobacterium-mediated transformation. Cell. 2006;125(4):749-60.

50. Liu S, Wang J, Han Z, Gong X, Zhang H, Chai J. Molecular mechanism for fungal Cell Wall recognition by Rice chitin receptor OsCEBiP. Structure. 2016; 24(7):1192-200.

51. Shinya T, Nakagawa T, Kaku H, Shibuya N. Chitin-mediated plant-fungal interactions: catching, hiding and handshaking. Curr Opin Plant Biol. 2015; 26:64-71.

52. Benedetti M, Pontiggia D, Raggi S, Cheng Z, Scaloni F, Ferrari S, Ausubel FM, Cervone F, De Lorenzo G. Plant immunity triggered by engineered in vivo release of oligogalacturonides, damage-associated molecular patterns. Proc Natl Acad Sci. 2015;112(17):5533-8.

53. Dangl JL, Horvath DM, Staskawicz BJ. Pivoting the plant immune system from dissection to deployment. Science. 2013;341(6147):746-51.

54. Dodds PN, Rathjen JP. Plant immunity: towards an integrated view of plantpathogen interactions. Nat Rev Genet. 2010;11(8):539-48.

55. Schwessinger B, Ronald PC. Plant innate immunity: perception of conserved microbial signatures. Annu Rev Plant Biol. 2012;63:451-82.

56. Choudhury FK, Rivero RM, Blumwald E, Mittler R. Reactive oxygen species, abiotic stress and stress combination. Plant J. 2017;90(5):856-67.

57. Leon J, Lawton MA, Raskin I. Hydrogen peroxide stimulates salicylic acid biosynthesis in tobacco. Plant Physiol. 1995;108(4):1673-8.

58. Rao MV, Paliyath G, Ormrod DP, Murr DP, Watkins CB. Influence of salicylic acid on $\mathrm{H}_{2} \mathrm{O}_{2}$ production, oxidative stress, and $\mathrm{H}_{2} \mathrm{O}_{2}$-metabolizing enzymes. Salicylic acid-mediated oxidative damage requires $\mathrm{H}_{2} \mathrm{O}_{2}$. Plant Physiol. 1997; 115(1):137-49

59. Xing F, Li Z, Sun A, Xing D. Reactive oxygen species promote chloroplast dysfunction and salicylic acid accumulation in fumonisin B1-induced cell death. FEBS Lett. 2013;587(14):2164-72.

60. Baxter A, Mittler R, Suzuki N. ROS as key players in plant stress signalling. J Exp Bot. 2014:65(5):1229-40.

61. Mittler R. ROS are good. Trends Plant Sci. 2017;22(1):11-9.

62. Chen Z, Zheng Z, Huang J, Lai Z, Fan B. Biosynthesis of salicylic acid in plants. Plant Signal Behav. 2009;4(6):493-6. 
63. Wildermuth MC, Dewdney J, Wu G, Ausubel FM. Isochorismate synthase is required to synthesize salicylic acid for plant defence. Nature. 2001; 414(6863):562-5.

64. Ribnicky DM, Shulaev W, Raskin II. Intermediates of salicylic acid biosynthesis in tobacco. Plant Physiol. 1998;118(2):565-72.

65. Gaffney T, Friedrich L, Vernooij B, Negrotto D, Nye G, Uknes S, Ward E, Kessmann $\mathrm{H}$, Ryals $\mathrm{J}$. Requirement of salicylic acid for the induction of systemic acquired resistance. Science. 1993;261(5122):754-6.

66. Anand A, Uppalapati SR, Ryu CM, Allen SN, Kang L, Tang Y, Mysore KS. Salicylic acid and systemic acquired resistance play a role in attenuating crown gall disease caused by Agrobacterium tumefaciens. Plant Physiol. 2008;146(2):703-15.

67. Palmer IA, Chen H, Chen J, Chang M, Li M, Liu F, Fu ZQ. Novel Salicylic Acid Analogs Induce a Potent Defense Response in Arabidopsis. Int J Mol Sci. 2019:20(13).

68. Diao P, Zhang Q, Sun H, Ma W, Cao A, Yu R, Wang J, Niu Y, Wuriyanghan H. miR403a and SA Are Involved in NbAGO2 Mediated Antiviral Defenses Against TMV Infection in Nicotiana benthamiana. Genes (Basel). 2019;10(7).

69. Alazem M, Kim KH, Lin NS. Effects of Abscisic Acid and Salicylic Acid on Gene Expression in the Antiviral RNA Silencing Pathway in Arabidopsis. Int J Mol Sci. 2019;20(10)

70. Song X, Ying X. Salicylic acid deficient Nicotiana benthamiana attenuated virus induced gene silencing but did not affect transgene-induced posttranscriptional gene silencing nor general biogenesis of microRNAs. Physiol Mol Plant P. 2019;106:276-80.

71. Lewsey MG, Carr JP. Effects of DICER-like proteins 2, 3 and 4 on cucumber mosaic virus and tobacco mosaic virus infections in salicylic acid-treated plants. J Gen Virol. 2009;90(Pt 12):3010-4.

72. Young Mo Koo AYHA. Salicylic acid as a safe plant protector and growth regulator. Plant Pathol J. 2020;1(36):1-10.

73. Alamillo JM, Saenz P, Garcia JA. Salicylic acid-mediated and RNA-silencing defense mechanisms cooperate in the restriction of systemic spread of plum pox virus in tobacco. Plant J. 2006:48(2):217-27.

74. Li Y, Muhammad T, Wang Y, Zhang D, Crabbe M, Liang Y. Salicylic acid collaborates with gene silencing to tomato defense against tomato yellow leaf curl virus (TYLCV). Pak J Bot. 2018;50:2041-54.

75. Gomez-Munoz N, Velazquez K, Vives MC, Ruiz-Ruiz S, Pina JA, Flores R, Moreno P, Guerri J. The resistance of sour orange to Citrus tristeza virus is mediated by both the salicylic acid and RNA silencing defence pathways. Mol Plant Pathol. 2017;18(9):1253-66.

76. Wang Y, Cong QQ, Lan YF, Geng C, Li XD, Liang YC, Yang ZY, Zhu XP, Li XD. Development of new potato virus $X$-based vectors for gene over-expression and gene silencing assay. Virus Res. 2014;191:62-9.

77. Huang X, Yu R, Li W, Geng L, Jing X, Zhu C, Liu H. Identification and characterisation of a glycine-rich RNA-binding protein as an endogenous suppressor of RNA silencing from Nicotiana glutinosa. PLANTA. 2019;249(6): 1811-22.

78. Lin AV. Indirect ELISA. Methods Mol Biol. 2015;1318:51-9.

79. Drygin YF, Blintsov AN, Grigorenko VG, Andreeva IP, Osipov AP, Varitzev YA, Uskov Al, Kravchenko DV, Atabekov JG. Highly sensitive field test lateral flow immunodiagnostics of PVX infection. Appl Microbiol Biotechnol. 2012;93(1): $179-89$.

80. Xu Y, Zheng X, Song Y, Zhu L, Yu Z, Gan L, Zhou S, Liu H, Wen F, Zhu C. NtLTP4, a lipid transfer protein that enhances salt and drought stresses tolerance in Nicotiana tabacum. Sci Rep. 2018;8(1):8873.

81. Protasiuk E, Olejnik M. Determination of salicylic acid in feed using LC-MS/ MS. J Vet Res. 2018;62(3):303-7.

82. Li W, Guo Y. RNA-Seq analysis of the Transcriptome of leaf senescence in tobacco. Methods Mol Biol. 1744:2018:331-7.

83. Yan G, Yang H. RNA sequencing data of tobacco inoculated with apple stem pitting virus. Data Brief. 2020:29:105106.

84. Jing XL, Fan MN, Jia G, Liu LW, Ma L, Zheng CC, Zhu XP, Liu HM, Wang XY A multifunctional protein encoded by turkey herpesvirus suppresses RNA silencing in Nicotiana benthamiana. J Virol. 2011;85(23):12792-803.

\section{Publisher's Note}

Springer Nature remains neutral with regard to jurisdictional claims in published maps and institutional affiliations.

\section{Ready to submit your research? Choose BMC and benefit from:}

- fast, convenient online submission

- thorough peer review by experienced researchers in your field

- rapid publication on acceptance

- support for research data, including large and complex data types

- gold Open Access which fosters wider collaboration and increased citations

- maximum visibility for your research: over $100 \mathrm{M}$ website views per year

At BMC, research is always in progress.

Learn more biomedcentral.com/submissions 